\title{
Assessing Rural Banks Effectiveness in Ghana
}

\author{
Abdul-Baaki Y Kadri ${ }^{1}$, Alhassan Bunyaminu ${ }^{2} \&$ Shani Bashiru ${ }^{3}$ \\ ${ }^{1}$ Credit \& Risk Department, International Commercial Bank, Accra, Ghana \\ ${ }^{2}$ Banking and Finance Department, University of Professional Studies, Accra, Ghana \\ ${ }^{3}$ School of Business and Management Studies, Accra Polytechnic, Accra, Ghana \\ Correspondence: Alhassan Bunyaminu, Banking and Finance Department, University of Professional Studies, \\ P.O. Box LG 149, Legon, Accra, Ghana. Tel: 233-24-6429-0969. E-mail: albun7@gmail.com
}

Received: November 1, 2012

Accepted: December 24, 2012

Online Published: January 25, 2013

doi:10.5539/ibr.v6n3p140

URL: http://dx.doi.org/10.5539/ibr.v6n3p140

\begin{abstract}
This study critically examines contemporary issues and lending activities to small scale farmers for agricultural production. The Agriculture sector is the mainstay of Ghana's economy and small scale farmers play a dominant role in the sector which explains why this study concentrates on this sector. A survey research was conducted using both structured and unstructured questionnaires. A total of 127 farmers, 18 key informants and 10 rural banks were interviewed. Descriptive and inferential statistics were used to analyse the effectiveness of rural banks. Allocations of the various loans (agriculture, cottage industry, trade and transport and others - social credit) in the rural banks' credit portfolio were significantly different among the four loans categories (ANOVA $p=9.6 \mathrm{E}-29$ ). From the tukey-kramer procedure, there was a difference in average amount of loan disbursed between agriculture and trade, and between agriculture and social credit with Q-Statistics of 3.84. The means for trade and social credit were larger than that of agriculture and by implication agriculture is treated less favourably in rural banks credit schemes and portfolio. These findings lend credence to the claim that rural banks are not sticking to their core mandate of prioritising credit provision to rural agriculture and have strayed into other endeavours.
\end{abstract}

Keywords: rural banks, small-scale farmers, credit, collateral

\section{Introduction}

Access to Secure and reliable institutional and secure of institutional credit by small-scale Ghanaian farmers are constrained by a myriad of conditions such as collateral security, often in the form of landed property, and stable employment that must be guaranteed by the employer. Besides the commercial and development banks are not keenly interested in advancing credit facilities to the Rural small scale farmers for reasons associated with spiralling transaction cost, rising incidence of default rates and the high risk (Essel \& Newsome, 2000).

These constraints situations have adversely affected agricultural activities in the rural areas of Ghana and have accelerated the worsening endemic poverty that is pervasive in these less privileged communities. To stem the gravity of these challenges, the concept, the concept of rural banking was introduced in 1976 by the Government of Ghana in partnership with the Bank of Ghana (BOG) as an alternative channel for providing financial intermediation at the rural levels (William and David, 2004). In pursuance of achieving the objectives of this concept, the rural banks (RBs) have devoted considerable amount of resources to the task of mobilising and allocating loanable funds as well as transforming and distributing risks and maturities by intermediating between rural savers and investors. While these efforts might have yielded positive results for some rural people and enterprises, it is uncertain whether or not RBs are serving the basic function for which they were established. This is because, there are significant anecdotal evidences to the fact that a high proportion of the RBs' loan portfolios are being diverted to salaried workers other than its intended beneficiaries - small-scale farmers. This unsubstantiated claim means there exists gaps in this area of study and this work seeks to find relevant answers to the question of whether rural banks have been effective in fulfilling their primary goal of providing credit to the rural farmer and whether evidence can be adduced to underpin the claim that the rural banks are releasing more credit to other economic endeavours to the detriment of rural agriculture. 


\section{The Study Area}

This study was conducted in Ghana. Ghana is located on the west coast of Africa, bordering the Gulf of Guinea, and between Cote d'Ivoire and Togo. It also lies 800 degrees north and 200 degrees west of the equator. The country has a total land area of 239,460 square kilometres (CIA, 2005). Of this, agricultural land constitutes 57 percent and only 20 percent of the agricultural land is under cultivation (Seini, 2002). Ghana has a population of 24.4 million as at 2010. Further, 63 percent of the population live in rural areas and 37 percent live in urban areas (ISSER, 2004).

Rural poverty in Ghana is 52 percent and urban poverty is 23 percent with more than one-half of the population living in the rural savannah zones continue to wallow in abject poverty. Ghana is ranked 135th out of 187 countries in the 2011 Human Development Index (HDI) released by the United Nations Development Programme (UNDP). It is a low-income food-deficit country with a per capita income of less than US\$340 per year (FAO, 2004). GDP for 2003 at current prices stands at US\$44.44billion (Bank of Ghana, 2004).

\section{Literature Review}

\subsection{Role of Financial Institutions on Agriculture Growth}

Researchers (Seini, 2002; Desai, 1989; Mellor, 1976; Rosen, 1975) have suggested that availability of finance is necessary for the adoption and diffusion of innovative and productivity-raising technologies in agriculture and consequently for the stimulation of agricultural growth. It is further asserted that improved technologies in agriculture are almost always being associated with increased demand for working capital (e.g. pesticides) or fixed capital (e.g. tractor) or both and for this reason, availability of finance is central to agricultural total factor productivity. In view of the fact that incomes of most farmers in developing countries are low, static and dependent on the variability of weather, effective financial intermediation in farming communities is of utmost significance in the sense that farmers use credit facilities to withstand current shocks and to provide insurance against possible future shocks and thus reduce the need to liquidate their productive assets (FAO, 1994; Habibullah, 1982; Bauer, 1952). Another role of financial intermediation at the rural levels, with slight but important shift in emphasis, is the fact that institutional credit is deeply required by rural farmers because of an inelastic growth of informal lenders who serve as alternative source of finance in rural communities. The resources of informal lenders are inadequate thereby diminishing their capacity to provide long term finance necessary for investments in productive assets such as irrigation, market infrastructure, tractors and farm implements (Lele, 1989; Rosegrant \& Siamwalla, 1988; Mellor, 1976). Moreover, development of small-scale farming systems is dependent, among other factors, on capital transfer (Kannapiran, 1994). While capital transfer in agriculture can be effected through saving mobilisation, the inadequate and unreliable nature of the deposit facilities which are being offered by the traditional lenders make the role of formal financial institutions relevant for the growth of agriculture (Desai, 1989; Von Pischke \& Donald, 1976). From the foregoing propositions, it can be concluded that agricultural growth is contingent on the development of effective financial markets.

\subsection{The Concept and Operations of Rural Banks in Ghana}

Rural banks (RBs) are unit banks owned by members of the rural community through the purchase of shares and are licensed by the Bank of Ghana (BOG) to provide financial intermediations in the rural areas, (Steel \& Andah, 2004). The RBs operate as commercial banks under the Ghanaian Banking Law 1989 (PNDCL 225), except that they cannot assume foreign exchange operations and the acceptance of valuable properties such as gold (Steel \& Andah, 2004). Association of Rural Banks (1992) states the following as some of the aims of RBs:

(1) To facilitate rural savings mobilisation;

(2) To offer credit and other banking services to rural producers;

(3) To act as an instrument for rural development;

In pursuance of the above objectives, the BOG has identified agriculture as a critical factor and consequently; it has mandated that agricultural loans should represent at least 50 per cent of any RB's loan portfolio at any particular point in time adding that cottage industry, and trading and transport should have a maximum allocation of 30 per cent and 20 per cent respectively (BOG, 1985); see table 1 . The BOG termed these mandatory sectoral allocations as direct production credit and any loan falling out of these sectors is termed social credit and should constitute a very minute fraction of RB loans. 
Table 1. Mandatory sectorial allocation of rural bank loans portfolio ${ }^{a}$

\begin{tabular}{ll}
\hline Sector & Credit Allocation \\
\hline Agriculture & A minimum of $50 \%$ of the Loan Portfolio \\
Cottage Industries ${ }^{\text {b }}$ & Approximately $30 \%$ of the Loan Portfolio \\
Trade and Transport & A maximum of $20 \%$ of the Loan Portfolio \\
\hline
\end{tabular}

Notes: a Source: The Bank of Ghana's Operational Manual for Rural Banks (1985). ${ }^{\mathrm{b}}$ Examples of Cottage Industries are bricks and tiles, construction, furniture making, tailoring etc.

However, Essel and Newsome (2000) have demonstrated, using case-control methodology, that RB credit lending operations have failed to meet the BOG stipulations. It was revealed from their study that credit for direct production such as crop production, trading and fishing constituted only about 15 per cent of the total loan portfolio in their case study bank. In the light of this discovery, Essel and Newsome (2000) argued that the low concentration of direct production credit in the case-study bank's loan portfolio is a weak test of the effectiveness of RBs. This situation might have been arisen from a high default rate position of the small-scale farmers. For example, Steel and Andah (2004) have asserted that standard commercial loans made by RBs in the 1980 s to direct production have resulted in portfolio performance problems. These problems, according to Steel and Andah (2004), became so serious to the extent that the RBs were grappling with the difficulty of depositors' withdrawal demands. By the early and mid 1990s, RBs had to undergo a number of changes so as to maintain public confidence and to expand their outreach, (BOG 1995). Following these changes, and the ardent desire to provide a more effective financial intermediation at the rural levels, RBs have now partnered with a number of Non Governmental Organisations (NGOs) who have developed expertise and capabilities in microfinance operations (Steel \& Andah, 2004; Chord, 2000; Quainoo, 1997). In this connection RBs in Ghana are now offering four types of financial products: individuals' savings with credit; individual savings with group credit; individual and group savings with credit; and group savings with credit, (Chord, 2000). Loans of this nature are typically short-term (4-6month) and amortised weekly with annualised interest rate of between 48 and 60 per cent, ibid. This is accompanied by a mandatory advance saving of 20 per cent of the principal and which saving is retained as security against the loan in addition to group or individual surety, (Steel \& Andah, 2004; Beinpuo, 2000). Consequently, RBs chalked much success in savings mobilisation and credit advances with Nsoatreman Rural Bank, for example, as at 1998, reporting a total of 25,587 depositors, 17,584 borrowers, 130 per cent operational self-sufficiency and portfolio in arrears under 4 per cent (See Steel \& Andah, 2004). It might be emphasised that interest rates of 48 to 60 per cent is by no means an exorbitant rate. Yet, the smaller-scale borrowers' ability of servicing RB credit is an ample demonstration of their commitment to participating in the formal financial markets.

The successes of RBs in Ghana seem to seriously mask the banks' failures in terms of their obligation to give priority to direct agricultural producers. Given agricultural planting cycle, seasonality of agricultural products and the huge capital base required for investment in productive asserts, it would not be difficult to construe that loans of 4 to 6 months duration and which are amortised weekly are adverse to agricultural growth and can potentially exclude agriculture from the RBs' credit portfolio. It might be wrong to conclude, therefore, that large percentage of the Nsoatreman Rural Bank loans went to agriculture as prescribed by BOG. This view may attract support from Nissanke and Aryeetey (1998) report that, as at 1993, RB's credit extended to the agricultural sector stood at 27 per cent. Obviously such percentage is less than the 50 per cent minimum allocation prescribed by BOG. Moreover, there is an ample evidence of RBs in Ghana accumulating excess liquidity, (Steel \& Andah, 2004; Beinpuo, 2000; Nissanke \& Aryeetey, 1998). Excess liquidity refers to situations where banks voluntarily increase their holdings of liquid assets (e.g. treasury bills) on a large scale in response to a rise in perceived default risks. This practice does not only reflect RBs Managers' degree of risk aversion but also impede the flow of investible funds to direct production as noted by Essel and Newsome, (2000): “...if the effectiveness of the Rural Bank program is to be improved, more credit must be shifted to direct producers who will invest in productive activities" (emphasis mine).

An important innovation in the operations of RBs in Ghana is the application of group-based lending schemes in almost all their financial products, (See Beinpuo, 2000; Chord, 2000). This gives an indication that RBs are trying to reduce their transaction cost by replacing multiple small loans to individual by a large loan to a group. It also points to the direction of RB's trying RBs are trying to leverage social sanctions to enforce repayment and as well use groups to reduce the effects of adverse selection and moral hazard; as has been demonstrated by the Grameen Bank. Conceptually, group-based lending is shrouded with lots of disagreements although its importance is well recognised in various literatures. Whereas researchers (Huppi \& Feder, 1990) maintain that 
group-based lending is effective under situations where the groups are homogenous and jointly liable for defaults, Sadoulet and Carpenter (2001); and Sadoulet (1999) held contrary views and attributed group effectiveness and risk reduction to heterogeneity. These authors argued that heterogeneous groups matching allows group risk pooling and creates insurance avenues in areas without insurance markets. This view seems relevant in the context of Ghanaian RFMs which have no insurance facilities for rural dwellers. In addition, the spread of group loans across different groups of farmers (e.g. livestock producers and crop producers) may serve to protect against total default in case of adverse climatic conditions. Therefore, it is logical to side with Sadoulet and Carpenter (2001).

Experts have also asserted that, loan monitoring and repayment enforcement are fundamental to the operations of RBs, (Essel \& Newsome, 2000). This may suggest that RBs place more emphasis on moral hazard. Should this be the case, then Aryeetey and Udry (1997) conclusion that commercial banks are more concerned with adverse selection than moral hazard leaves much to be desired.

Evidence exists in both contemporary and extant literature that, little research has been conducted on the effectiveness of Ghanaian RBs on agricultural growth at rural levels. Essel and Newsome (2000), for example, have analysed RB effectiveness in Ghana but their research focused largely on the effects of RB credit on rural development. More so, the sample size they chose was less than 1 per cent of the population, and what is more, their study did not have a wider geographical spread. Based on these shortcomings their conclusions may not give a true reflection of the effectiveness of RBs in Ghana. Against this backdrop, it remains uncertain on whether or not, it is uncertain whether or not RBs are fulfilling the basic functions for which they were created. An in-depth study of RB effectiveness is, therefore, appropriate in the growing body of work in development finance. In the light of these submissions, this study tries to overcome some of the methodological deficiencies in the Essel and Newsome (2000) study by increasing the sample size; choosing the appropriate sampling frame and expanding the coverage.

\section{Research Design and Methodologies}

To successfully carry out the research, the survey strategy was used. Patrick and Steve (2005) assert that a survey can be anything from a short paper and pencil feedback to an intensive one-to-one in-depth interview. Similarly, Saunders, Lewis and Theornhill (2000) proclaim that the survey strategy allows for the collection of large amount of data in a highly economic way from a sizeable population based on questionnaire.

The research used two populations: an aggregate of all Rural Banks (RBs) in Ghana and the collection of all small-scale farmers in Ghana. The aggregate of the population were as follows: ten (10) Rural Banks (RBs) which serves as a representation of each region in the study area and the collection of fifteen (15) small-scale farmers.

During the sampling stage, both probability and non-probability sampling methods were applied. The probability method employed in the study was simple random sampling via the lottery approach. The reason behind the choice of that methodology was to provide equal chances for the selection of RBs and the local farmers. The non-probability technique applied was the purposive sampling. With purposive sampling the sample is 'hand-picked for the research', (Denscombe, 2004). The sample is selected with a specific purpose in mind, and that purpose reflects the particular qualities of the people or events chosen and their relevance to the topic of the investigation.

To conduct the empirical investigation of RBs effectiveness, a descriptive research design together with inferential statistics was used. The research design was selected based on the nature of the study - a focus on breadth and depth. Descriptive research design seeks to portray an accurate profile of a situation, events or persons.

The study used both qualitative and quantitative research instruments. The quantitative design instrument used for this study was a questionnaire while the qualitative design instruments were key informants. Two types of questionnaire and interview schedules were designed to elicit information from the three samples. The first questionnaire was for the small-scale farmers. The second was for the RBs. The questionnaire consist mainly structured and open-ended questions.

\section{Results of the Analysis}

This section analyses and discusses the data elicited through the questionnaires and the interview schedules. In particular, it assesses the credit portfolio of RBs and its implications for agricultural financing, the constraints small-scale farmers encounter in their bid to access rural banks credit, and the effectiveness of rural banks in supporting small-scale farmers in Ghana. 


\subsection{Access to and Constraints of Rural Banks' Credit}

Different sources of credit used by farmers as well as the constraints small-scale farmers face in their bid to access RBs credit were investigated. Table 2 provides the results of the empirical investigation.

Table 2. Access to RB credit and constrains therein

\begin{tabular}{lll}
\hline Rural Bank Credit & $\%$ & No. of Farmers \\
\hline Source Of Credit & & 127 \\
1. Rural Bank & 20.00 & 127 \\
2. Money Lenders & 10.00 & 127 \\
3. Friends and Family & 39.00 & 127 \\
4. Self-savings & 23.00 & 127 \\
5. Others & 8.00 & \\
\hline Reasons for Failure to Secure RBs Credit Facilities & & \\
1. Collateral Security & 60.00 & 102 \\
2. Average Deposit Required & 20.00 & 102 \\
3. Fixed Income Guarantees & 12.00 & 102 \\
4. Up to Date Farm Records & 8.00 & 102 \\
\hline
\end{tabular}

Source: Survey data, 2010.

From the data above, it can be observed that whereas nearly three-quarters of the respondents financed their agricultural operations through informal credit sources, a little over a quarter financed their farms operations through the formal credit sources. This may suggests the failure of the formal financial sector to satisfy the existing credit demand of the small-scale farmers and thus buttress the assertion that the bulk of rural credit to the agricultural sector comes from the informal source (IFAD, 2000).

It can be observed further that of those who relied on informal source to finance their farm operations, 39\% relied on credit from family and friends, $10 \%$ on moneylenders and $23 \%$ on self-savings. A high figure of $39 \%$ of respondents relying on informal credit sources was found to rely on family and friends suggesting that farmers seek to avert the risk inherent in borrowing from the other sources by relying on close relatives.

Regarding the formal sources, $20 \%$ of respondents were found to finance their projects through RBs while only $8 \%$ relied on the other commercial and development banks. This finding contradicts that of Seini (2002) which stated that the Agricultural Development Bank of Ghana (ADB) is the main source of finance to the Ghanaian agricultural sector. This notwithstanding, the finding may imply an existence of segmentation in the credit market. Whereas ADB serves the needs of many commercial and cash crop farmers such as cocoa and coffee farmers, the RBs finance the activities of the "real" small-scale and low-income food crop farmers.

The research also revealed a number of reasons why small-scale farmers are not able to secure credit from RBs. Among the respondents were farmers who did not seek credit from the RBs, $60 \%$ blamed their inability to access RBs credit on the difficulties associated with the required collateral security, $20 \%$ cited the difficulties in meeting the required average deposit as their bane, $12 \%$ attributed their failure on constraints in providing evidence of fixed income that is guaranteed by an employer, and the remaining $8 \%$ had no need for RB credit.

It was also discovered from the research that farmers who accessed RBs credit met a number of banks' conditions as prerequisite. When the conditions were ranked, using a scale of 1 to 4 ( 1 being the easiest and 4 the most difficult), on the basis of the difficulties with which respondents satisfy them it was discovered that provision of collateral security was the most difficult condition to satisfy, while provision of up-to-date records was the easiest (see figure 1). Specifically, $48 \%$ of the respondents ranked collateral as the most difficult condition. This observation gives weight to the assertion of those farmers who blamed the requirement of collateral security as their main bottle-neck to access RB credit.

Information elicited from the RBs established that collateral security was the most important consideration of RBs in granting loans to farmers, while satisfying the condition of good record system was the least important consideration (see Table 3). When the conditions were ranked using a scale of 1 to 4 ( 1 being the least important consideration and 4 the most important consideration) on the basis of their importance as RBs consideration for granting loans to farmers, it became unfolded that $50 \%$ of the respondent RBs regard collateral security as the most important consideration for granting loans to farmers and thus gives further credence to the previous claims. 


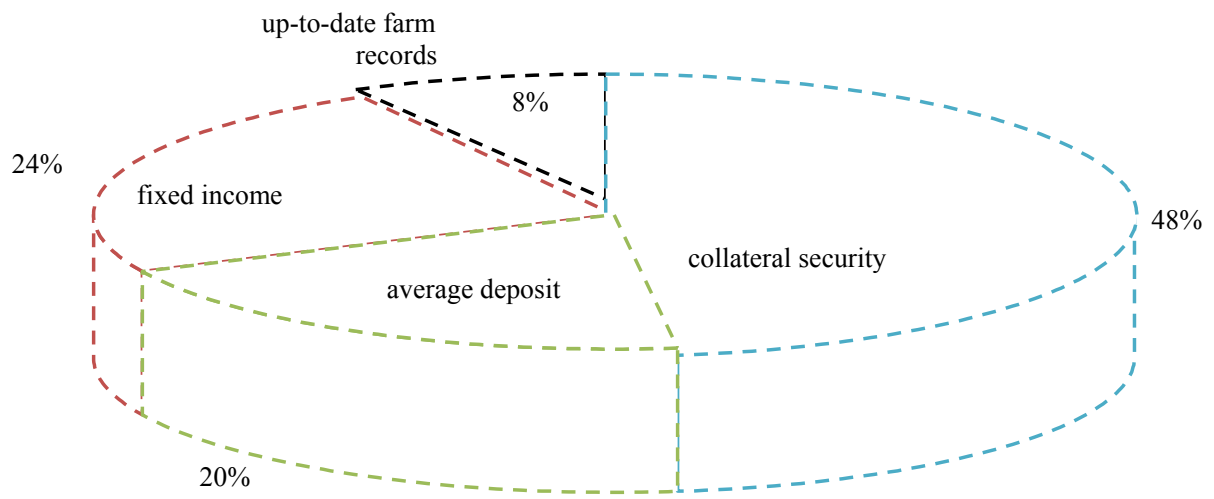

Figure 1. Rural bank credit recipients and their perception about loan conditions difficulties Source: Survey data, 2010.

Table 3. Most important considerations of RBs in granting loans to farmers

\begin{tabular}{lll}
\hline Factors & $\%$ & No of Rural Banks \\
\hline Collateral Security & 50.0 & 10 \\
Deposit Pattern/Average Deposit & 25.0 & 10 \\
Duration of Loan Facility & 9.0 & 10 \\
Size of Loan Facility & 12.0 & 10 \\
Good Records System & 4.0 & 10 \\
\hline
\end{tabular}

Source: Survey data, 2010.

Discussions with the key informants confirmed the importance of collateral security in RBs' lending policies. The key informants shed more light on the kind of security often accepted by the banks. Fixed assets with high commercial value such as land and building are often accepted.

One important observation that emerged from this study is the contrasting role collateral security plays in loan provision. Whilst collateral security constitutes the most formidable condition that small scale farmers grapple with, it is ironically the overarching condition considered by RB's in the exercise of granting loans. This finding squares with that of MOFA/ASIP which concluded in 1994 in its "Partner in Rural Agricultural Investment" that collateral security was one of the major factors constraining small-scale farmers' access to institutional credits.

Another poignant observation that emerged from these results is linked to the observation that $8 \%$ of those who did not use RB credit by virtue of the fact that they had no need for credit may have two important implications. First possible interpretation can be that, it may not necessarily mean the rural farmers do not need credit. It could be that the type of loans they require are nonexistent and thus imply that RBs do not serve the needs of farmers who want to undertake large scale commercial farming. Second, it provides an indication that the remaining $64 \%$ of respondents who are unable to access RBs' credit because of collateral security really need credit for direct production. This therefore suggests a huge unmet demand for RB credit by vast majority of rural small-scale farmers. This financing gap if not will only serve to compound the farmers' already precarious economic conditions. In addition, where the farmers are fortunate to have access to the RB credit, the facility will be rationed and this will impose constraints on their investment initiatives.

This study also finds that average deposit is also a major condition considered by RBs in granting loans to small-scale farmers. This condition might have been designed based on two major considerations. First, the strong desire on the part of the RB managers to design collateral substitutes in order to facilitate low-income borrowers' access to RB credit and thus reduce the need for heavy reliance on commercially valuable properties as collateral securities. The other factor might reflect the RB managers' belief in the assumptions which had been advocated by people like Bouman (1989) and Porter (1964) that poor and low-income people do not embark on savings; and in order to facilitate deposit mobilisation from those people, the formal finance providers must demand forced savings as a precondition to loans. Whichever of the factors holds true, the fact is unmistakable: the required deposit is a burden on the farmers because savings may be difficult to maintain over lean and hunger periods if farmers do not have other sources of income. In addition, the farmers may have a higher preference to hold their savings in physical productive assets. By implication for farmers to meet the deposit requirement of the RBs, they must liquidate or transform their physical productive assets into financial 
forms. This transformation may expose the farmers to greater risk and difficulties in terms of acquiring farm implements and other production related assets during farming season. This may consequently affect the farmers' productive base. Once their productive base is adversely affected, it will ignite a vicious circle where the rural farmers' income takes a nose dive thereby disabling them from fending for their families. In this light, risk aversion and related risk insurance behaviour would undoubtedly affect the farmers' decision to save in financial forms especially the case in Ghana where interest rates on savings are far below the inflation rate. In order words, the farmers' inability to provide the required deposit could be attributed to their degree of risk aversion.

\subsection{Credit Use, Loan Cycle and Loan Terms}

Among the respondents who had used RBs' credit facilities, $40 \%$ of them used the loans to acquire raw materials such as seed stock and agro-chemicals, $20 \%$ used the loans for equipment, $16 \%$ used the loan to purchase sheep for rearing, $12 \%$ had diverted the loan to other uses, and $12 \%$ used the loan for the purchase of oxen to help in transporting goods to and from farms. Figure 2, presents the results of the findings.

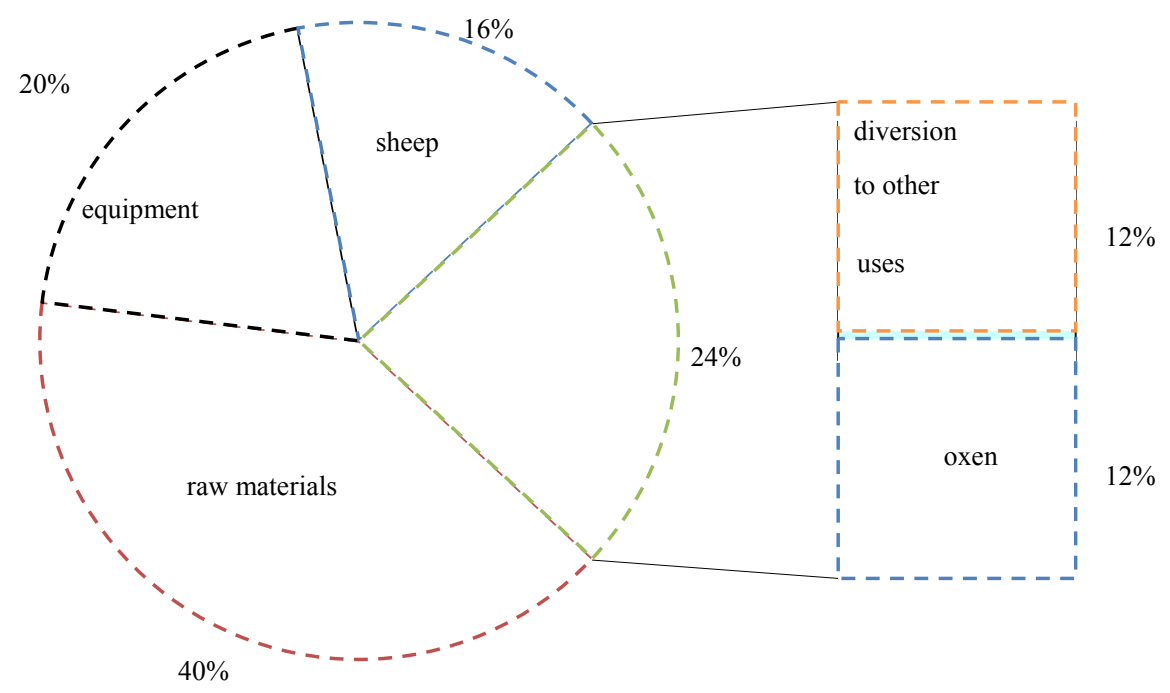

Figure 2. Uses of credit

Source: Survey data, 2010.

A number of observations were made regarding small-scale farmers diversion of loans for purposes other than those for which they were granted. This may suggests that some farmers abuse the RBs credit and may, somehow, confirm the argument that the mere fact that entrepreneurs cite finance as a constraint does not necessarily imply they are all good candidates for credit or would use credit productively (Von Pischke, 1991). Nevertheless, the situation may also reflect a laxity on the part of the RBs in the monitoring and supervision of their loans. For instance, an interview with some of the key informants revealed that most of the RBs are in the habit of relying on the agricultural Extension Officers to appraise and monitor agricultural loans. Obviously, this practice may result in lax monitoring and supervision since the Extension Officer may be confronted with a conflict of interest with particular reference to satisfying the needs of the bankers or the farmers. In favour of who, then, does the loyalty of the extension officers lie? The effectiveness of the process is, therefore, fraught with a serious doubt.

Interestingly, over $70 \%$ of the loan recipients used the facility for agricultural purposes. This suggests that the farmers really take farming seriously, and if given financial support they will invest it productively. This will no doubt have a trickledown effect on the farmer and farmer's families and consequently help in Putting a downward pressure on poverty.

The average credit cycle - that is, the number of times a particular borrower secured a credit - observed in the sample mean was 3.84 with a median of 3 and a standard deviation of 1.81(see Table 4). The small difference between the mean and the median coupled with a low standard deviation about the mean indicates that farmers get access repeatedly to loans from the RBs. 
Table 4. Summary of loan cycle

\begin{tabular}{ll}
\hline Mean & 3.84 \\
Median & 3.00 \\
Maximum & 9.00 \\
Minimum & 2.00 \\
Standard Deviation & 1.81 \\
No.of Farmers & 25.00 \\
\hline
\end{tabular}

Source: Survey data, 2010.

This development might be attributed to RBs' ability to identify and institute proper screening and contract enforcement mechanisms. For instance, when respondents were asked if they had ever defaulted in their loan repayment, all the 25 respondents $(100 \%)$ answered in the negative. The reasons provided for non defaults were as follows: (1) $56 \%$ said they fear reprisal from group members, (2) $32 \%$ said they want forthcoming loans, and (3) $12 \%$ said they have a moral obligation to repay. These findings sharply contrast those of Nissanke and Aryeetey (1995) who found that defaults in repayments were most acute among small agricultural loans in Ghana.

Recipients of RB credit were requested to specify the duration of their loans (loan terms). Average loan term observed in the sample was 5.04 months with a standard deviation of 1.43 months. These figures run contrary to what were observed from the bankers' responses. From the bankers' responses, the average loan term observed was 10.35 months with a standard deviation of 3.14 months. In the light of these observed differences, a $t$-test for difference between two means was performed to test whether or not the observed differences are significant. The results showed the differences to be significant. Table 5 provides the results of the $t$-Test.

On the surface, the observed differences cast doubt on the credibility of either the farmers or the bankers. However, this disparity could be due to the fact that where as the farmers might be reporting the duration between the period when the loan was received and the period they are required to repay, the bankers might be reporting periods that include delinquency time with a view to allowing for the collection of loans which would have otherwise been written off. For instance, Nissanke and Aryeetey (1995) reported that over 85 per cent of Bank Managers in Ghana do not believe that delinquency is a wilful act in agricultural loans and often the managers refinance most projects with a view that the projects would pay back when revived.

Table 5. A measure of the level of significance in the disparity between the information on loan terms

\begin{tabular}{ll}
\hline & Data \\
\hline Hypothesized Difference & 0 \\
Level of Significance & 0.05 \\
Population 1 Sample (Rural Banks) & \\
Sample Size & 10 \\
Sample Mean & 10.35 \\
Sample Standard Deviation & 3.14 \\
Population 2 Sample (Small-scale Farmers) & \\
Sample Size & 25 \\
Sample Mean & 10.35 \\
Sample Standard Deviation & 5.04 \\
\hline
\end{tabular}

Source: Survey data, 2010.

Table 6. The t-Test on the disparity between the information on loan terms

\begin{tabular}{ll}
\hline Intermediate Calculations & \\
\hline Population 1 Sample Degrees of Freedom & 9 \\
Population 2 Sample Degrees of Freedom & 24 \\
Total Degrees of Freedom & 33 \\
Pooled Variance & 4.176182 \\
Difference in Sample Means & 5.31 \\
$t$-Test Statistic & 6.944497 \\
\hline
\end{tabular}

Source: Survey data, 2010. 
Table 7. The results of hypothesis test on the disparity between the information on loan terms

\begin{tabular}{ll}
\hline Two-Tailed Test & \\
\hline Lower Critical Value & -2.03452 \\
Upper Critical Value & 2.034515 \\
$p$-Value & $6.17 \mathrm{E}-08$ \\
Reject the null hypothesis & \\
\hline
\end{tabular}

Source: Survey data, 2010 .

\subsection{Amount of Loans Disbursed to and Recovered from Agricultural Sector}

The past five years' (2005-2010) empirical data for the amount of loans disbursed to and recovered from the agricultural sector by the sampled RBs when subjected to regression analysis, showed a positive relationship. Figure 3 presents the graph of a linear model. This result implies that as farmers repay their loan amounts in a timely fashion there is a possibility that more loans will be disbursed to them.

As to how much increases in disbursement farmers are likely to receive as they honour their loan obligations was an issue to be explored. Fortunately, a linear model which is underpinned by the equation, $y=0.3045 x+16.851$ predicts an inelastic response. This equation holds that for each percentage increase in the independent variable (recovery rate); the fitted model predicts a less than percentage increase in the dependent variable (disbursement). That is to say that for every 100 per cent recovery RBs made from agricultural loans, holding other factors constant; there is the probability that RBs will increase its loans to agricultural sector by approximately 30 per cent.

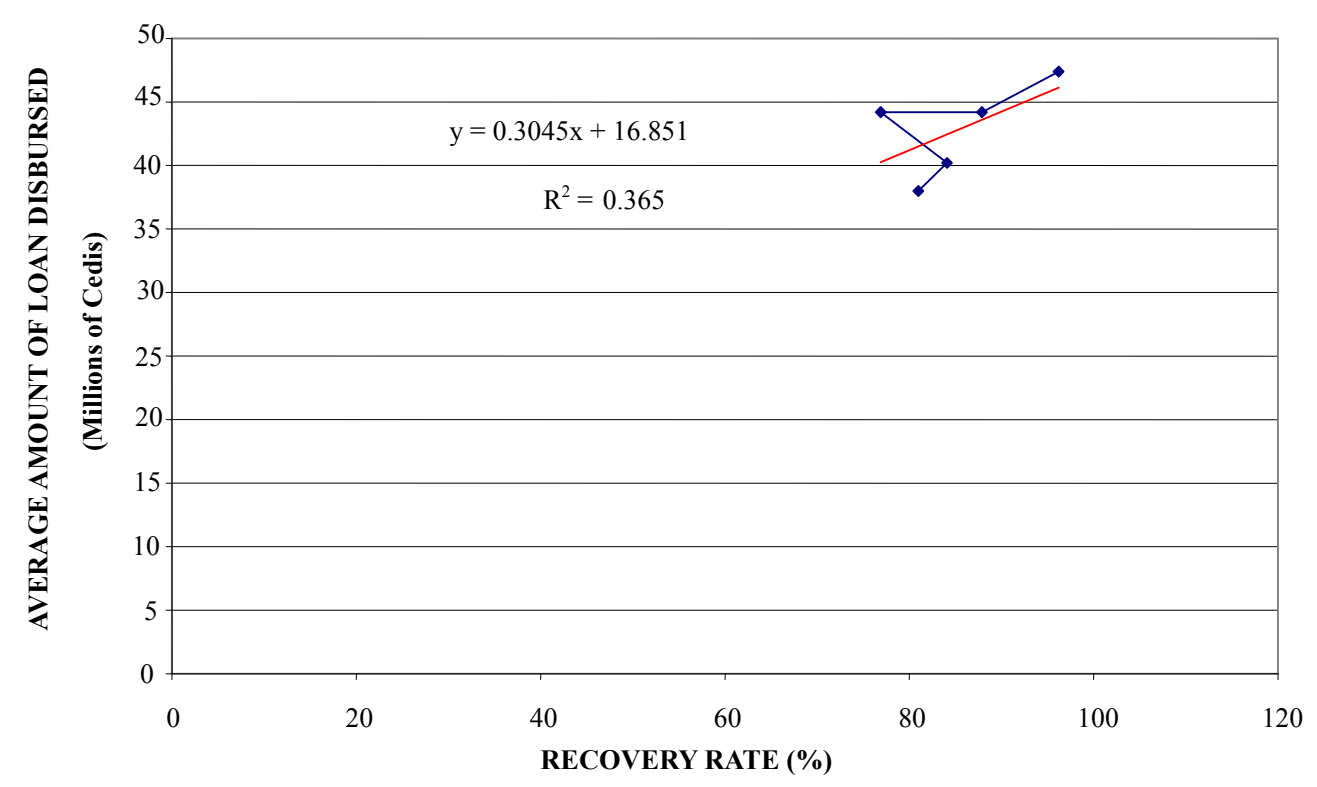

Figure 3. Relationship between amount of agricultural loans disbursed and amount recovered Source: Survey data, 2010.

Since recovery rate had affected the amount of loans disbursed, a co-efficient of determination was calculated to determine how much does recovery rate influence disbursement. The calculated co-efficient of determination value of 0.365 imply that approximately 37 per cent of the factors that influence RBs' lending policies are attributable to loan recovery rate. One implication this analysis may present is that RBs' loans disbursed to the agricultural sector are determined largely by loans recovery rate although other factors may still weigh heavily. These factors include the perception on the part of RB bank managers that agriculture is a risky venture and loan conditions such as the provision of collaterals and average deposit will continue to reign.

\subsection{Credit Portfolio and an Assessment of Rural Banks' Effectiveness in Ghana}

This section examines RBs' loan portfolio and its implication on agricultural financing. It also assesses the effectiveness of RBs in Ghana. 
Credit portfolio is the number and types of loans held by lenders at any particular point in time (Capiński \& Zastawniak, 2003). The lending policies of financial service providers determine the type and number of persons or enterprises that come under the lenders' portfolio and also the percentage portfolio allocation each person or enterprise receives (Schmidt \& Kropp, 1987). Portfolio characteristics such as loan terms and the cost of loan play a crucial role in lenders decision, (Nissanke \& Aryeetey, 1995). Table 8 provides the credit portfolio and its underlying characteristics.

Table 8. Rural credit portfolio characteristics

\begin{tabular}{lllllll}
\hline & Mean & Median & Max & Min & Std.dev. & No. of Banks \\
\hline LOAN CATEGORY & & & & & & \\
Agriculture & 7.3 & 7 & 11 & 5 & 1.55 & 10 \\
Cottage Industry & 7.3 & 8 & 15 & 3 & 3.99 & 10 \\
Trading & 38.3 & 37 & 44 & 32 & 3.75 & 10 \\
Others & 47.1 & 48 & 48 & 40 & 2.36 & 10 \\
LOAN TERMS & 10.35 & 9.5 & 24 & 4 & 3.14 & 10 \\
INTEREST RATES & 26.9 & 27 & 33 & 20 & 3.45 & 10 \\
\hline
\end{tabular}

Source: Survey data, 2010.

\subsection{Portfolio Composition and Allocation}

It was observed that RBs credit portfolio is composed of agricultural, cottage industry, trade and transport, and social (others) loans. Each of these had a respective percentage allocation of 7.3\%, 7.3\%, 38.3\%, and 47.1\% (See Figure 4).

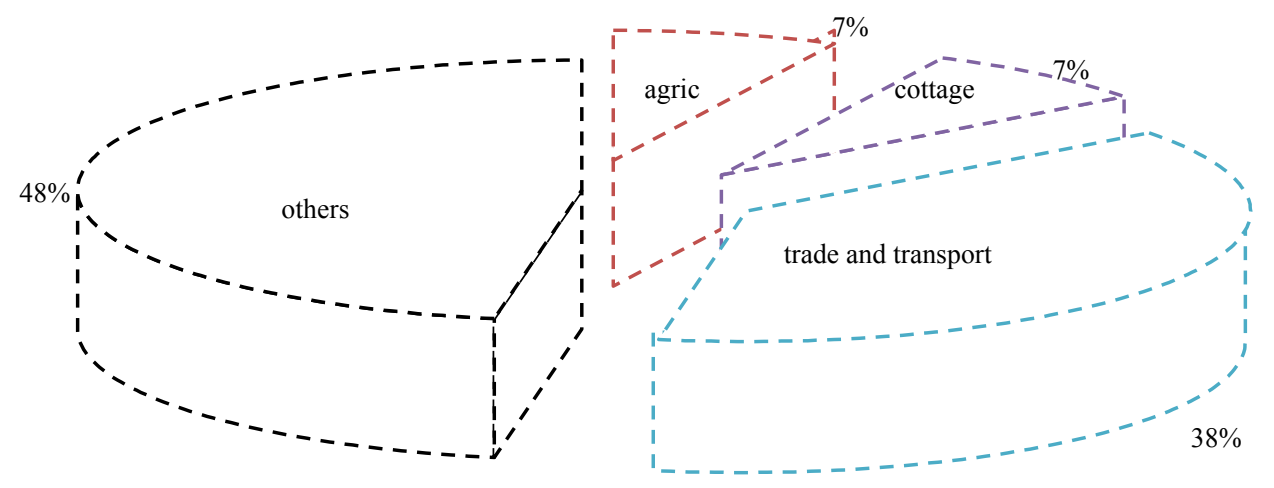

Source: Field data, 2010.

Figure 4. Rural bank credit portfolio

These results suggest that agricultural loans are given less priority in terms of the amount of loan disbursed. In addition, the close disparity in the mean and median of agricultural loans suggests a slight variation in the treatment of agricultural loans in RBs' credit portfolio. This generates that the practice is wide spread among the RBs throughout Ghana - a practice that contravenes BOG's stipulations which mandates a higher proportion of credit for agriculture.

However, it was uncertain whether the observed differences in the means of the constituents of the RBs' credit portfolio was so significant to merit a conclusion that the agricultural sector is treated less favourably by the RBs in Ghana.

In this regards, an analysis of variance (ANOVA) was performed to measure the level of significance of the differences in the means of the percentage allocation of the various portfolios. In other words, the first hypothesis of the study - that is, there is no significant difference in the treatment of RBs loans as far as the stipulations of BOG are concerned — was tested. Table 9 provides the results of the hypothesis test. 
Table 9. Differences in the means of the percentage allocation of the various portfolios

\begin{tabular}{|c|c|c|c|c|c|c|}
\hline $\begin{array}{l}\text { ANOVA: Single Factor } \\
\text { SUMMARY }\end{array}$ & & & & & & \\
\hline Groups & Count & Sum & Average & Variance & & \\
\hline Agric & 10 & 73 & 7.3 & 2.677778 & Agric & 10 \\
\hline Cottage & 10 & 73 & 7.3 & 14.45556 & & Cottage \\
\hline Trading & 10 & 383 & 38.3 & 12.9 & & \\
\hline Others & 10 & 471 & 47.1 & 7.433333 & 3.45 & 10 \\
\hline \multicolumn{7}{|l|}{ ANOVA } \\
\hline Source of Variation & $S S$ & $d f$ & $M S$ & $F$ & $P$-value & $F$ crit \\
\hline Between Groups & 12918.8 & 3 & 4306.267 & 459.7438 & $9.6 \mathrm{E}-29$ & 2.866266 \\
\hline Within Groups & 337.2 & 36 & 9.366667 & & & \\
\hline Total & 13256 & 39 & & & & \\
\hline
\end{tabular}

Source: Survey data, 2010.

From Table 9 above, the $\mathrm{F}$ calculated (F) was observed to be 459.74 and the critical bound of $\mathrm{F}$ ( $F$ critical) was also observed to be 2.87 . Since the F calculated is above the critical bound of $\mathrm{F}$, the hypothesis is rejected. In addition, since the $P$-value, 9.6E-29, is far less than the level of significance, 0.05 , the hypothesis is further rejected. There is therefore enough evidence to conclude that the four group means are not the same. That is to say, they differ more than would be expected by chance alone. However, it may be argued or possible that there were extreme differences in a few of the means chosen and which, if so, will provide a context for the rejection of the ANOVA results. To verify this, a post hoc test, using the Tukey-Kramer procedure, was performed to apply "corrections" to the sample in order to offset the effects of choosing the most extreme means; and to determine which of the means is significantly different from the other. Table 10 provides the results of the Tukey-Kramer procedure.

Table 10. Tukey-Kramer procedure

\begin{tabular}{|c|c|c|c|c|}
\hline Group & & Sample Mean & & Sample Size \\
\hline Agriculture 1 & & 7.3 & & 10 \\
\hline Cottage 2 & & 7.3 & & 10 \\
\hline Trade 3 & & 38.3 & & 10 \\
\hline Others (social) 4 & & 47.1 & & 10 \\
\hline Comparison & Absolute Difference & Std. Error of Difference & Critical Range & Results \\
\hline Group 1 to Group 2 & 0 & 0.96781541 & 3.7164 & Means are not different \\
\hline Group 1 to Group 3 & 31 & 0.96781541 & 3.7164 & Means are different \\
\hline Group 1 to Group 4 & 39.8 & 0.96781541 & 3.7164 & Means are different \\
\hline Group 2 to Group 3 & 31 & 0.96781541 & 3.7164 & Means are different \\
\hline Group 2 to Group 4 & 39.8 & 0.96781541 & 3.7164 & Means are different \\
\hline Group 3 to Group 4 & 8.8 & 0.96781541 & 3.7164 & Means are different \\
\hline \multicolumn{5}{|l|}{ Other Data } \\
\hline Level of significance & Numerator d.f. & Denominator d.f. & MSW & Q Statistic \\
\hline 0.05 & 4 & 36 & 9.366667 & 3.84 \\
\hline
\end{tabular}

Source: Survey data, 2010.

From the Tukey-Kramer procedure, there is a difference in average amount of loan disbursed between agriculture and trade; and between agriculture and others (social credit). Since the means for trade and others are larger than the mean for agriculture, it implies that agriculture is treated less favourably in RBs credit portfolio.

In sum, these tests results (1) confirm the claim that RBs allocate a larger proportion of their loan portfolio to beneficiaries other than the small-scale farmers; (2) suggest that RBs violate the BOG's stipulations; and (3) suggest that RBs are not doing much to help the agricultural sector of Ghana. This observation confirms earlier research conducted by Essel and Newsome (2000) in Ghana. In their study, the researchers reported a shift in the focus of RBs lending approaches which were characterised by the banks' concentration on social credit at the expense of credit for agricultural purposes. This practice of RBs of depriving the agricultural sector of adequate finances will no doubt have a serious implication for agricultural growth in Ghana. 


\subsection{Testing for Rural Banks Effectiveness}

One of the objectives of RBs in Ghana is to act as an instrument in stimulating rural economic growth. Since most rural economies depend on agriculture and also since economic growth is measured by a sustained increase in product (output), growth in agricultural output is used as a proxy to measure RBs' effectiveness in the light of their contribution to the agricultural sector. However, in view of the meagre levels at which the credits are given, the high interest rates as well as the short repayment terms, it is doubtful whether the difference in the output levels of the farmers who take the loans and that of those who do not is of any significance. Against this background, the second hypothesis of the study was constructed and which states that there is no significant difference between the output levels of farmers who use RB credit and those who do not. An increase in output was measured by Yes/No response. Using Fisher's Exact Test to compare the output levels between the two groups, a significant difference was found. Table 11, presents the results of the Fisher's test.

This result implies that farmers do experience significant increase in output when they have access to RB credit. This may be a result of short-term financing of working capital needs such as fertilizers and pesticides. However, this result should be cast in a proper light. Only a small fraction of the farmers in the sample were able to secure RBs' credit as a result of collateral security constraints.

Table 11. Comparison of the output levels between farmers who have access to rural bank credit (RBF) and farmers without access to rural bank credit (NRBF)

\begin{tabular}{|c|c|c|c|}
\hline \multicolumn{4}{|c|}{$\begin{array}{l}\text { Fisher's Exact Test } \\
\text { The two-sided P value is } 0.0341 \text {, considered significant. } \\
\text { The row/column association is statistically significant. }\end{array}$} \\
\hline \multicolumn{4}{|c|}{ Odds Ratio } \\
\hline \multicolumn{4}{|c|}{ Odds ratio $=2.000$} \\
\hline \multicolumn{4}{|c|}{$\begin{array}{l}95 \% \text { Confidence Interval: } 1.093 \text { to } 3.660 \\
\text { (using the approximation of Woolf.) }\end{array}$} \\
\hline \multicolumn{4}{|c|}{ Data analyzed } \\
\hline & $\mathrm{RBF}$ & $\mathrm{NRBF}$ & Total \\
\hline YES & $\begin{array}{l}75 \\
(38 \%)\end{array}$ & $\begin{array}{l}60 \\
(30 \%)\end{array}$ & $\begin{array}{l}135 \\
(68 \%)\end{array}$ \\
\hline NO & $\begin{array}{l}25 \\
(13 \%)\end{array}$ & $\begin{array}{l}40 \\
(20 \%)\end{array}$ & $\begin{array}{l}65 \\
(33 \%)\end{array}$ \\
\hline Total & $\begin{array}{l}100 \\
(50 \%)\end{array}$ & $\begin{array}{l}100 \\
(50 \%)\end{array}$ & $\begin{array}{l}200 \\
(100 \%)\end{array}$ \\
\hline
\end{tabular}

Source: survey data, 2010.

Considering this fact against the backdrop of the significant difference observed between the farmers who had access to the facility and those without the access; it might be construed that the more farmers are able to secure $\mathrm{RB}$ credit, the more are the chances that they will experience significant increase in output and thus justify the effectiveness of RBs. In other words, the effectiveness of RBs is undermined by their low outreach.

\section{Conclusions}

The study had the objective of assessing RBs effectiveness in Ghana and their impact on small-scale agriculture. A survey research was conducted using both structured and unstructured questionnaire. A total of 127 farmers, 18 key informants and 10 RBs were interviewed. The study combined both descriptive and inferential statistics in the analysis.

The results showed that farmers who accessed RBs credit experienced significant increases in output (yield). This implies that RBs are effective in stimulating agricultural production. However, the results showed further that a great number of small-scale farmers (over $60 \%$ ) are still underserved by RBs as a result of the constraints posed by request for collateral security. That is to say that, RBs have lower outreach, which undermines their effectiveness. The results also revealed that the bulk of RBs credit is diverted to beneficiaries other than the small-scale farmers. This practice also serves to dilute the RBs effectiveness and further gives an indication that the RBs are not serving the basic function for which they were created.

Based on the above, this study concludes that RBs in Ghana are of little effectiveness as far as provision of credit to rural small scale farmers are concerned with its concomitant negative effect on agricultural growth. 
For RBs credit to make a significant impact on agricultural growth, more attention should be given to medium and long-terms financing to the small scale rural farmer. The current practice of concentrating on meeting short-term working capital needs of rural farmers is at best a short term fix that cannot sustain agricultural expansion.. It is only medium and long-term financing that can lead to the necessary structural changes in agriculture such as the development of irrigation farming. This can be achieved by improving the supply of loanable funds to the agricultural sectors and by extension to the small-scale farmers. The BOG can facilitate this process by lowering the minimum reserve ratio required from RBs. The RBs on the other hand can assist by developing or adopting more innovative approaches to lending and these approaches should aim at: (1) increasing farmers' access to RB credit, (2) decreasing the attendant high transaction cost, and (3) minimising counterparty risk. The RBs might wish to adopt approaches such as group-based lending, nucleus-outgrower lending schemes and inventory credit programmes.

The nucleus-outgrower scheme like the group-based lending has the benefit of replacing multiple small loans to individual outgrowers by a lump sum to a group of outgrowers without the associated high cost of lending to the RBs. Also lending, most often, is in kind and thus reduces the problems of fungibility in agricultural loans. Moreover, outgrowers have a ready market for their produce and this is likely to reduce counterparty risk.

Animation can be incorporated into the group-based lending programmes. The animation should be aimed at not only to stimulate $\mathrm{RB}$ beneficiaries to their responsibilities of loan repayments, but also to train them in bookkeeping and enterprise management skills. This can be done in partnership with the Agricultural Extension Services of Ghana. The experience of Freedom of Hunger, an International NGOs, in this type of group loan schemes should be tapped.

The inventory credit programme is an innovation that combines credit with marketing to overcome the immediate post-harvest dip of producer prices. The programme should be provided with technical assistance in areas of post harvest technology, as some of the produce may be perishable. TechnoServe Incorporated, an International NGO, provides a leading role in this programme and the RBs can leverage their experiences.

The supply of loanable funds to agricultural sector can also be improved via more thorough deposit mobilisation strategies. Systematic understanding of normative social belief systems and effective marketing strategies such as sustaining of customer satisfaction and loyalty are relevant in this regard.

\section{References}

Aryeetey, E., \& Udry, C. (1997). The Characteristics of Informal Financial Markets in sub-Sahara Africa. Journal of Africa Economies, 6(1).

Association of Rural Banks. (1992). Annual Reports. (Unpublished report on file at the Association of Rural Banks). Accra, Ghana, The Bank of Ghana.

Bank of Ghana. (1985). Bank of Ghana Operational Manual for rural Banks. Accra, Ghana, J'Piter Printing Press Ltd.

Bank of Ghana. (1995). Restructuring of Rural Banks. The Bank of Ghana, Accra, Ghana.

Bank of Ghana. (2004). Quarterly Economic Bulletin. January-March 2004. Retrieved from www.bog.gov.gh/publica/2004/Qtr12004/Q1,\%202004.pdf.

Bauer, C. K. (1952). Proceedings of the International Conference on Cooperative Credit. Barkley, California.

Beinpuo, F. (2000). Group Intermediation in Ghana: The Credit with Education Programme, Freedom from Hunger, Accra.

Bouman, F. J. A. (1989). Small, Short and Unsecured: Informal Finance in Rural India. Delhi: Oxford University Press.

Capinski, M., \& Zastawniak, T. (2003). Mathematics for Finance: An Introduction to Financial Engineering. London: Springer-verlag.

Central Intelligence Agency. (2005). The 2005 World Fact Book. The CIA. Retrieved from http://www.cia-gov/cia/publications/factbok/goes/gh.htm1\#Intro

CHORD. (2000). Inventory of Ghanaian Micro-Finance Best Practices. Report for Ministry of Finance: Non-Banking Financial Institutions Project, Accra.

Denscombe, M. (2004). The Good Research Guide: for small-scale research projects (2nd ed.). Berkshire, England: Open University Press. 
Desai, B. M. (1989) Objectives and role of Institutional Finance for Agricultural and Rural Development. Vikalpa, 14, 2.

Donald, G. (1976). Credit for Small Farmers in developing Countries. Boulder, CO: West View Press.

Essel, T. T., \& Newsome, A. M. (2000). Effectiveness of Institutional Credit for Rural Development in Africa: A case Control Study of Rural Banks in Ghana. Journal of Sustainable Development in Africa, 2(1).

Food and Agricultural Organisation. (1994). Rural Poverty in the 1990s, in Rural Development Special Paper No. 15. Accra, Ghana: Ghana University Press.

Food and Agricultural Organisation. (2004). Proceedings from Twenty-Seventh FAO Regional Conference for Asia and the Pacific: Financing for Agricultural Development. Beijing, China

Habibullah, B. (1982). Financial Intermediation and Rural Economic Development. Bank Parikrama, 7, 3-4.

Huppi, M., \& Feder, G. (1990). The Role of Groups and Credit Cooperatives in Rural Lending. The World Bank research Observer, 5(2) 187-204. http://dx.doi.org/10.1093/wbro/5.2.187

Institute of Statistical Social and Economic Research. (2003). Overview of the Ghanaian Economy. Legon, Ghana: The ISSER. Retrieved form http://www.isser.org/SGER\%202003\%20final.htm\#_Toc78196027

International Fund for Agricultural Development. (2000). Rural Financial Services Project in Ghana. Pre-appraisal Mission Working Paper: "Re-packing the Rural Finance Sub-sector in Ghana poverty Gender and Rural Informal Sector Perspectives" and Working Paper: "Strategy for Mainstreaming Gender with a Specific Focus on Northern Ghana.”

Kannapiran, C. (1994). Sustainable Rural Credit for Agricultural Development in Papua New Guinea. Papua New Guinea Journal of Agriculture, Forestry and Fisheries, 37(1), 104-116.

Lele, U. (1989). Managing Agricultural Development in Africa: Three Articles on Lessons from Experience. The World Bank. Washington DC, (MADIA Discussion Paper No. 2).

Mellor, J. W. (1976). The New Economics of Growth: Strategy for India and the Developing World (Chapter 17). Ithaca, New York: Cornell University Press.

Nissanke, M., \& Aryeetey, E. (1998). Financial Integration and Development. London: Routledge Studies in Development Economics.

Patrick, M., \& Steve, C. (2005). Research Methods (3rd ed.). London: Routledge.

Porter, R. C. (1964). The Promotion of Banking Habits and Economic Development. Journal of Development Studies, 2, 346-66. http://dx.doi.org/10.1080/00220386608421196

Quainoo, A. A. (1997). A Strategy for Poverty Reduction through Micro-Finance: Experience, Capacities and Prospects. Accra: Draft Report of a Study Commissioned by Government of Ghana and World Bank.

Rosegrant, M. W., \& Siamwalla, A. (1988). Government Credit Programme: Justifications, Benefits, and Costs. In John W. Mellor \& Raisuddin Ahmed (Eds.), Agricultural Price Policy for Developing Countries. Baltimore and London: The John Hopkins University Press.

Saunders, N. K. M., Lewis, P., \& Theornhill, A. (2000). Research Methods for Business Students (2nd ed.). England: Pearson Education Limited.

Schimidt, R. H., \& Kropp, B. W. (1987). Rural Finance: Guiding Principles. Bonn, Germany: GTZ.

Steel, W. F., \& Andah, D. O. (2004). Rural and Micro Finance Regulation in Ghana: Implications for Development and Performance of Industry. International Conference on Ghana at the Half of the Century, 18-20.

Von Pischke, J. D. (1991). Finance at the Frontier: Debt Capacity and the Role of Credit in Private Economy. Washington, DC: The World Bank.

Von Pischke, J. D. (1997). Preconditions for Sustainable Agricultural Finance and Credit Systems. Agricultural Finance in Transition Economies, Proceedings of OECD Expert Meeting, Paris, 18-19.

Von Pischke, J. D., Adams, D. W., \& Donald, G. (Eds.). (1983). Rural Financial Markets in Developing Countries: Their Use and Abuse. Baltimore: The John Hopkins University Press.

Wayo Seini, A. (2002). Agricultural Growth and Competitiveness Under Policy Reforms in Ghana. ISSER Technical Publication Series, No. 61, Legon, Accra: The Institute of Statistical, Social and Economic Research (ISSER). 